\title{
Simulation of SARS-CoV-2 Aerosol Emissions in the Infected Population and Resulting Airborne Exposures in Different Indoor Scenarios
}

Special Issue:

Special Issue on COVID-19 Aerosol Drivers, Impacts and Mitigation (X)

\section{OPEN ACCESS}

Received: August 23, 2020

Revised: October 7, 2020

Accepted: October 12, 2020

\section{${ }^{*}$ Corresponding Author:}

michael.riediker@alumni.ethz.ch

\section{Publisher:}

Taiwan Association for Aerosol Research

ISSN: $1680-8584$ print

ISSN: 2071-1409 online

(c) Copyright: The Author(s).

This is an open access article distributed under the terms of the Creative Commons Attribution License (CC BY 4.0), which permits unrestricted use, distribution, and reproduction in any medium, provided the original author and source are cited.

\author{
Michael Riediker ${ }^{1}$, Christian Monn $^{2}$ \\ ${ }^{1}$ Swiss Centre for Occupational and Environmental Health (SCOEH), Winterthur, Switzerland \\ ${ }^{2}$ State Secretariat for Economic Affairs (SECO), Section Working Conditions, Bern, Switzerland
}

Some of the SARS-CoV-2 virus can become airborne. Estimates suggest that the exhaled viral emissions from an infected person with high viral load can result in critical airborne concentrations in poorly ventilated small rooms. This project aimed to develop an indoor scenario simulator to rapidly assess the potential exposure in different indoor situations. It uses the estimates of a Monte Carlo simulation for the viral emission strength of breathing, speaking softly and loudly. The resulting emitter strength feeds a near-field far-field well-mixed room model. The indoor scenario simulator allows testing different room and ventilation sizes, wearing different masks, and different levels of physical activity and speech types for different percentiles of emitter strength in the population. The scenario tests suggest that in typical situations such as moderately ventilated offices, small shops, trains, buses, or carpool, very high emitters $\left(99^{\text {th }}\right.$ percentile and above) not wearing masks are likely to cause concentrations with an elevated risk of infection via aerosols, especially in the near-field of the infected person. Speaking loudly and high levels of physical activity further increase the concentrations. If all persons wore surgical (hygiene) masks or filtering respirators with a higher protection factor, the expected concentrations were low in most situations, even if the viruses were released by "super-emitters" (top 1 permille emitter). This indoor scenario simulator may be helpful for decision makers as well as workplace and facility experts to assess and improve existing protection concepts, and to guide indoor exposure assessment campaigns.

Keywords: SARS-CoV-2, Exhaled aerosol, Indoor air, Scenario simulator, Inhaled dose

\section{INTRODUCTION}

In late 2019, a new form of coronavirus disease (COVID-19) emerged in China and rapidly spread throughout the world (Coronaviridae Study Group of the International Committee on Taxonomy of Viruses, 2020). Three routes of transmission for this virus called SARS-CoV-2 seem most relevant: by contact of contaminated surfaces, by directional spray processes of large droplets expelled during coughing, sneezing and speaking, and by a fogging-like process from exhaled small aerosols released from breathing and speaking but also sneezing and coughing (Chu et al., 2020; Jones, 2020; Riediker, 2020). Faecal transmission was also proposed (Tian et al., 2020) but not yet documented to actually occur. A particularity of SARS-CoV-2 is that it seems to be spread to an important part by people who are not yet or never symptomatic of COVID-19 (Furukawa et al., 2020). Research suggests a community transmission rate of about 10 to $15 \%$ (Li et al., 2020) and a secondary household attack rate in the range of 35\% (Liu et al., 2020a), which suggests that transmission is driven by a relatively small number of individuals. Indoors, airborne transmission seems to be very important (Zhang et al., 2020), as evidenced also by numerous "superspreading" events where one person infected many others present in the same room even when respecting distancing and hygiene rules. Indeed, in hospitals with COVID-19 patients, the virus was detectable in the air (Liu et al., 2020b) 
The dose necessary to infect humans is subject to ongoing research. For many viruses, a few hundred to a thousand plaque forming units (PFU) are sufficient to infect a human (Schröder, 2020; Yezli and Otter, 2011). For SARS-CoV-1 (the epidemic that started in 2002), it was suggested that at a dose of 280 plaque forming units, $50 \%$ of the people would get infected, while the lowest dose that infected somebody was estimated at 16 PFU (Watanabe et al., 2010). For SARS-CoV-2 (causing COVID-19 in the current coronavirus epidemic), virologists estimate that the infective dose is in a similar range though slightly higher than for SARS-CoV-1 (Chandrashekar et al., 2020; Karimzadeh et al., 2020; Pfefferle et al., 2020; Schröder, 2020). PFUs are not identical to the number of viral copies determined by polymerase chain reaction (PCR), since several hundred „Virus copies" can be present per PFU (Sampath et al., 2005). When aiming to prevent infections, a "critical dose" that should not be exceeded can be defined as a few PFU, which probably corresponds to a few hundred viral copies determined by PCR. Research on the minimal infective dose of SARS-CoV-2 is ongoing and may still move this "critical dose" up or down.

Earlier, we showed that the risk of having elevated, potentially infectious concentrations of SARS-CoV-2 in the air seems to depend strongly on the viral load in the lung lining liquid that is released into the air (Riediker and Tsai, 2020). The viral load in sputum and nasal swabs determined by PCR was reported to range from a few hundred viral copies per millilitre to over $10^{10}$ copies $\mathrm{mL}^{-1}$ (Lou et al., 2020; Wölfel et al., 2020; Zheng et al., 2020; Zou et al., 2020).

The aim of this study was to develop a tool for the rapid simulation of scenarios of SARS-CoV2 transmission through aerosols under different indoor conditions. It starts with a refined analysis of the ability of a SASR-CoV-2 infected person to emit the virus by simulating the virus-emission source strength distribution in the general population. Input variables of this simulator are the virus emitter strength, loudness of speech, physical activity of emitter and exposed person, room characteristics such as room size, ventilation rate and average wind speed, and types of masks worn by emitter and exposed person. The output produced are estimates of the concentration and inhaled dose in the room and near the emitter.

\section{METHODS}

We modelled the distribution of the viral emission strength in the population with a Monte Carlo simulation: we started by randomly sampling the viral load of a person from the distribution in the general population published in a preprint (Jones et al., 2020) and used it to calculate the virus concentration contained in the different sizes of exhaled microdroplets. This base viral emission was next combined with a random draw from the distribution of the ratio of the emitted aerosol compared to the median amongst people reading a text at loud voice (Asadi et al., 2019), specifically a log-normal distribution with a geometric mean of 0.982 and a geometric standard deviation of 1.964. We then approximated the amount that is likely to stay airborne for prolonged time in turbulent air by retaining in each size fraction what would pass through an inhalable particulate matter $\left(\mathrm{PM}_{10}\right.$ ) impactor, as described earlier (Riediker and Tsai, 2020). The resulting emission strength was finally scaled to talking quietly (25\% larger and $5 x$ in number compared to being quiet) and loudly (10x in number compared to talking quietly) using published difference factors (Asadi et al., 2019). This Monte Carlo simulation was repeated 100,000 times. It provided the emission strength distribution for low, median, high, very high and super-emitters, corresponding to the $10^{\text {th }}, 50^{\text {th }}, 90^{\text {th }}, 99^{\text {th }}$ percentile, and $999^{\text {th }}$ permille, respectively.

The exposure in the room was modelled with a deterministic mass balance near-field far-field well-mixed room model (Nicas, 2016) with a spherical near-field and an interzonal flow rate defined by the half globe surface and the average wind speed in the room (Keil and Zhao, 2017). It uses the above-defined emission strengths for different percentiles of quiet, low or loud speech (in virus per $\mathrm{cm}^{3}$ emitted air) combined with the respiratory volume. The respiratory volume was defined for sitting/resting at $7500 \mathrm{~cm}^{3} \mathrm{~min}^{-1}$, for low activity at 15,000 $\mathrm{cm}^{3} \mathrm{~min}^{-1}$ and for high activity at $45,000 \mathrm{~cm}^{3} \mathrm{~min}^{-1}$ (Ramos et al., 2015). The inactivation of the virus in the air was addressed by including the published half-life of the $50 \%$ tissue culture infective dose of aerosolised SARS-CoV-2 (van Doremalen et al., 2020) as a decay term. Filtering facepiece respirators were assumed to pass fit testing and were assigned the minimally required retention efficiency of $80 \%$ for FFP1, 95\% for FFP2 and $99 \%$ for FFP3. For the exhalation efficiency, respirators without 
valve were arbitrarily assigned a factor of $80 \%$, since they were qualitatively described to be slightly better at reducing the exhalation flow than surgical masks (Hui et al., 2012; Milton et al., 2013), while those with a valve were given a retention efficiency of $5 \%$ at exhalation. A minireview of the exhalation and inhalation efficiencies of surgical masks and simple cloth face coverings (Table 1 ) suggested the inhalation and exhalation retention efficiency of well-fitting surgical/hygiene masks to be $75 \%$, and that of simple single-layer cloth face coverings to be $25 \%$.

The indoor scenario simulator allows a user to modify the following input parameters: the room volume, the air exchange rate (AER), the average air speed in the room, the time spent by an infected person in the room, the types of masks worn by infected people and bystanders, the type of emitter (from low to super-emitter), the physical activity, the loudness of speech, and the critical dose of virus copies (determined by PCR) that should not be exceeded. AER was defined as the rate of replacing the indoor air by virus-free air, either high-efficiency filtered or fresh outdoor air.

The output parameters of the simulator are the estimated viral levels in the far-field (the background in the room) and the near-field (within $60 \mathrm{~cm}$ of the emitter), the cumulative inhaled number of viruses at these two locations and the time until a critical virus dose is reached for different physical activities of the bystander.

The simulator provides the exposure and inhaled dose of a bystander who enters the room at the same time as the emitter, thus at the beginning of the build-up of the room concentration. To obtain the inhaled dose of a bystander entering a room where an infected individual already spent time, one needs to simulate two time points: $\mathrm{t} 1=$ (the time spent by the emitter until the bystander enters), and the time $\mathrm{t} 2=\mathrm{t} 1+$ (the time spent by the bystander), to obtain the dose (late entering) $=$ dose $(\mathrm{t} 2)-$ dose $(\mathrm{t} 1)$. The simulator is available in the online supplementary data.

For defining scenarios in public transport, we obtained volumes and AER from Swiss public transport providers. Worst-case assumptions for AER in naturally ventilated offices were based on federal work inspector observations, while long-distance bus and airplane data were taken from public sources (major manufacturer websites and Wikipedia). Car volumes and AER correspond to mid-size (large family) vehicles, as described in a representative sampling study in Californian cars (Fruin et al., 2011). We also tested scenarios that were documented as superspreading events in the literature (Hamner et al., 2020; Hijnen et al., 2020; Lu et al., 2020; Park et al., 2020). The room sizes were estimated from the descriptions given in the papers and from

Table 1. Retention efficiency of face coverings, community masks and surgical masks described in the literature.

\begin{tabular}{|c|c|c|c|c|}
\hline Source & Mask type & Exhalation retention & Inhalation retention & Testing conditions \\
\hline (He et al., 2013) & Surgical mask & not assessed & $65 \%$ to $90 \%$ & $\begin{array}{l}\text { Manikin head, multiple } \\
\text { breathing rates }\end{array}$ \\
\hline (Wen et al., 2013) & Surgical masks & not assessed & $\begin{array}{l}60 \% \text { to } 85 \% \text { (filtering } \\
\text { material itself > 95\%) }\end{array}$ & Manikin head \\
\hline (Milton et al., 2013) & Surgical masks & $\begin{array}{l}70 \% \text { to } 74 \% \text { (fine to } \\
\text { total aerosol) }\end{array}$ & not assessed & $\begin{array}{l}\text { Viruses exhaled by influenza } \\
\text { patients }\end{array}$ \\
\hline $\begin{array}{l}\text { (Zangmeister et al., } \\
\text { 2020) }\end{array}$ & $\begin{array}{l}\text { Different layers } \\
\text { and cloth types }\end{array}$ & $20 \%$ to $32 \%$ (one layer) & $20 \%$ to $32 \%$ (one layer) & $\begin{array}{l}\text { Filtration efficiency only, no } \\
\text { fit test }\end{array}$ \\
\hline $\begin{array}{l}\text { (Rengasamy et al., } \\
\text { 2010) }\end{array}$ & $\begin{array}{l}\text { Different cloth } \\
\text { types }\end{array}$ & $10 \%$ to $60 \%$ & $10 \%$ to $60 \%$ & $\begin{array}{l}\text { Filtration efficiency only, no } \\
\text { fit test }\end{array}$ \\
\hline (Davies et al., 2013) & Surgical mask & $85 \%$ (airborne) & $60 \%$ to $89 \%$ & $\begin{array}{l}\text { Human exhalation with } \\
\text { microbe test, fit test for } \\
\text { inhalation }\end{array}$ \\
\hline (Davies et al., 2013) & Homemade mask & 78\% (airborne) & $50 \%$ to $60 \%$ & $\begin{array}{l}\text { Human exhalation with } \\
\text { microbe test, fit test for } \\
\text { inhalation }\end{array}$ \\
\hline (Checchi et al., 2005) & Surgical mask & not assessed & 85 to $86 \%$ & Manikin head \\
\hline (Bałazy et al., 2006) & Surgical mask & not assessed & $15 \%$ to $80 \%$ & Manikin head \\
\hline (Li et al., 2006) & Surgical mask & not assessed & $95 \%$ & $\begin{array}{l}\text { Human exposed to } \mathrm{KCl} \\
\text { aerosol }\end{array}$ \\
\hline
\end{tabular}


online identified pictures showing the locations. To test whether airborne transmission was a plausible explanation, we erred to the "healthy side" and assumed AER to be 3 exchanges per hour, which is in the upper range of what can be expected in such places.

The Monte Carlo statistics were calculated using Stata/SE 15.1 (StataCorp, College Station, TX, USA). The indoor scenario simulator was implemented using Excel 365 for Mac (Microsoft, Redmond, WA, USA) without macros and by using only formulas that are in use for at least 15 years. Compatibility tests were done using Excel 2016 for Windows (Microsoft, Redmond, WA, USA), LibreOffice 6.3 for Windows, Mac and Linux (The Document Foundation), and Numbers 10.1 for Mac (Apple Inc, Cupertino, CA, USA).

\section{RESULTS AND DISCUSSION}

\subsection{Monte Carlo Modeling of Viral Emitter Strength}

The Monte Carlo simulation provided the estimated distribution of the viral emitter strength for breathing only, speaking quietly/normally and speaking loudly. Fig. 1 shows the input distributions and the resulting estimated distribution while speaking quietly, which is multimodal and skewed to the left. Table 2 shows the key statistics of the emission strength in function of emitter loudness. Skewness and kurtosis are identical because the scaling was done after the Monte Carlo simulation. The top one-permille emission (99.9\%) of a person breathing quietly is similar to what we reported in our earlier simulation as the upper range of a breathing emitter (Riediker and Tsai, 2020).

We applied the indoor scenario simulator to indoor workplaces such as offices, transport, walk-in businesses and documented superspreading events. We tested the effects of the parameters that often differ in these situations, namely time spent in the room, mask wearing,
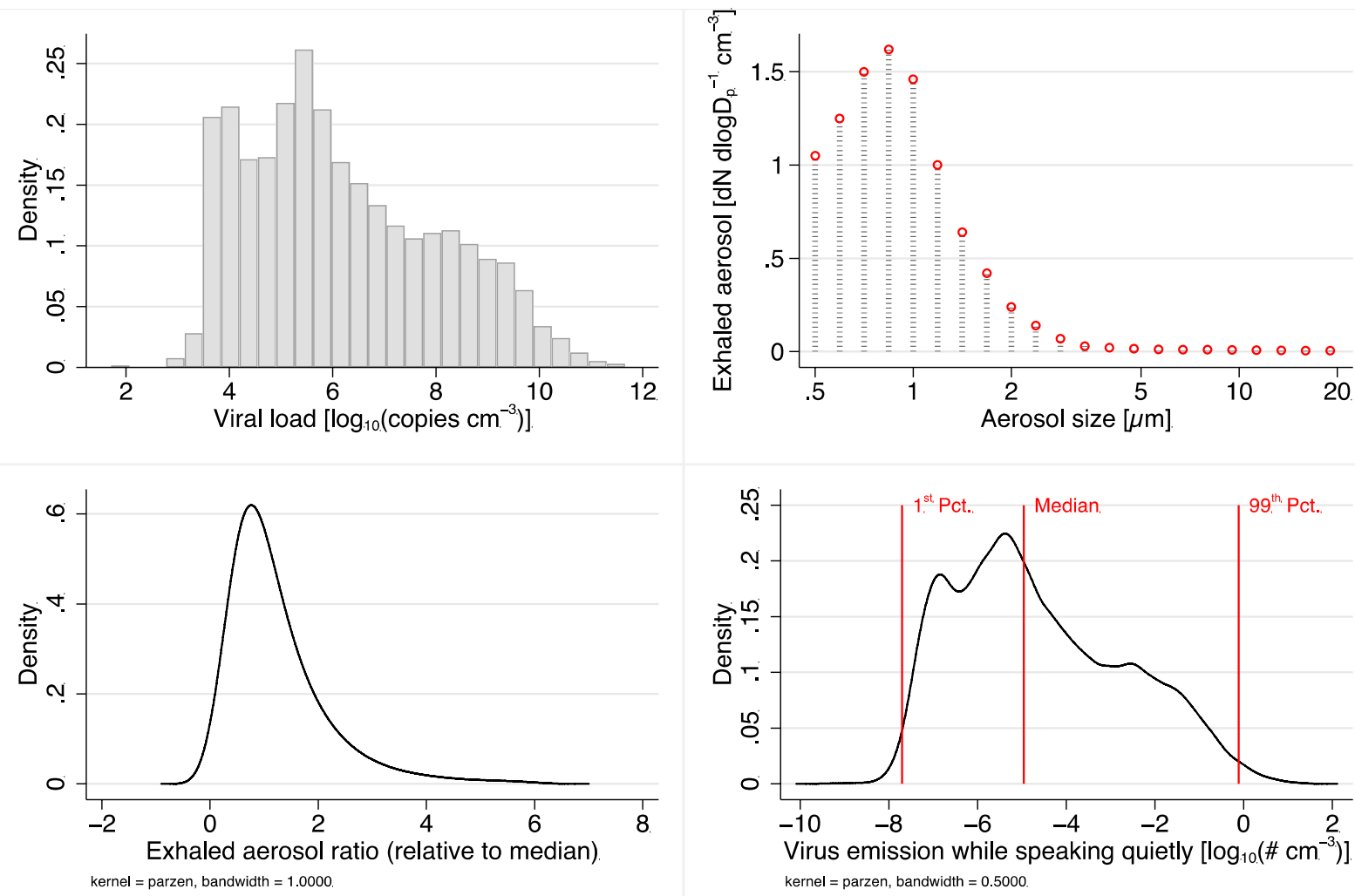

Fig. 1. Input distributions used to run the Monte Carlo simulation and resulting distribution of the infected population's viral emission strength while speaking quietly. A: Density plot of the viral load in the population; B: Median size-distribution of aerosol emissions; C: Density plot of the variability of aerosol emissions in the population relative to the median (delogarithmized for visualization purposes); D: density plot of the resulting viral emission strength scaled to speaking quietly. 
Table 2. Statistics of viral emission strength distribution obtained from the Monte Carlo simulation for breathing only, speaking quietly, and speaking loudly. (a) Percentiles with names were used in the indoor scenario simulator with the corresponding emitter type name.

\begin{tabular}{llll}
\hline Statistics & $\begin{array}{l}\text { Breathing } \\
\text { [copies cm }\end{array}$ & $\begin{array}{l}\text { Speaking quietly } \\
\text { [copies cm }\end{array}$ & $\begin{array}{l}\text { Speaking loudly } \\
\text { [copies cm }\end{array}$ \\
\hline Mean & $4.35 \mathrm{E}-03$ & $4.25 \mathrm{E}-02$ & $4.25 \mathrm{E}-01$ \\
Standard deviation & $5.19 \mathrm{E}-02$ & $5.07 \mathrm{E}-01$ & $5.07 \mathrm{E}+00$ \\
Variance & $2.69 \mathrm{E}-03$ & $2.57 \mathrm{E}-01$ & $2.57 \mathrm{E}+01$ \\
Skewness & $3.60 \mathrm{E}+01$ & $3.60 \mathrm{E}+01$ & $3.60 \mathrm{E}+01$ \\
Kurtosis & $1.90 \mathrm{E}+03$ & $1.90 \mathrm{E}+03$ & $1.90 \mathrm{E}+03$ \\
$1 \%$ & $2.04 \mathrm{E}-09$ & $1.99 \mathrm{E}-08$ & $1.99 \mathrm{E}-07$ \\
$5 \%$ & $5.50 \mathrm{E}-09$ & $5.37 \mathrm{E}-08$ & $5.37 \mathrm{E}-07$ \\
Low $10 \%$ (a) $^{25 \%}$ & $1.09 \mathrm{E}-08$ & $1.06 \mathrm{E}-07$ & $1.06 \mathrm{E}-06$ \\
Normal 50\% (a) & $7.40 \mathrm{E}-08$ & $7.23 \mathrm{E}-07$ & $7.23 \mathrm{E}-06$ \\
$75 \%$ & $1.14 \mathrm{E}-06$ & $1.11 \mathrm{E}-05$ & $1.11 \mathrm{E}-04$ \\
High 90\% (a) & $6.62 \mathrm{E}-05$ & $6.47 \mathrm{E}-04$ & $6.47 \mathrm{E}-03$ \\
$95 \%$ & $1.96 \mathrm{E}-03$ & $1.91 \mathrm{E}-02$ & $1.91 \mathrm{E}-01$ \\
Very high 99\% (a) & $8.22 \mathrm{E}-03$ & $8.02 \mathrm{E}-02$ & $8.02 \mathrm{E}-01$ \\
Super 99.9\% (a) & $7.96 \mathrm{E}-02$ & $7.77 \mathrm{E}-01$ & $7.77 \mathrm{E}+00$ \\
$99.99 \%$ & $6.31 \mathrm{E}-01$ & $6.16 \mathrm{E}+00$ & $6.16 \mathrm{E}+01$ \\
\hline
\end{tabular}

room size, and ventilation rates. Activity and speaking were set to "resting" (sitting, standing) and "quiet" (not making sounds) unless otherwise mentioned. The average wind speed in the room (used to calculate the interzonal near-field flow) was always set at $0.1 \mathrm{~m} \mathrm{~s}^{-1}$.

\subsection{Office Scenarios: Focus on Room Parameters, Emitter Strength, Mask Types and Time in Room}

A series of cases in indoor workplaces such as offices were modeled (Table 3 ) to understand the influence of room parameters (volume), ventilation (AER), emitter strength, wearing mask and mask type, time spent in the room, and speaking. The simulation of a small office shows that for a scenario with a normal emitter (one emitting median virus quantities) spending a few hours in the room, virus levels in the room (far-field) and also in the near-field remain very low, resulting in a dose of 0.02 copies. However, already for high emitters (90\%), cumulative inhaled doses can reach the range of hundreds to thousands inhaled virus copies in situations with poor ventilation (around 0.1 per hour AER) and the emitter talking loudly over a longer time period. It thus reaches a range that seems to be critical for viral infections (Sampath et al., 2005; Watanabe et al., 2010; Yezli and Otter, 2011; Karimzadeh et al., 2020; Schröder, 2020). In rooms with very high AER (e.g., open windows all the time), or in large rooms such as open-space offices with standard ventilation rates, concentrations are relatively low as long as the high or very high emitter does not talk loudly nor continuously. The presence of a super-emitter in a meeting room talking frequently or even giving a speech was simulated to result in considerably high doses. If we simulated the same scenario with everyone in the room wearing a surgical mask, the scenario still showed elevated doses.

\subsection{Scenarios for Businesses with Walk-in Customers}

We next looked at the situation of small businesses with walk-in customers such as small boutiques or repair shops, fine dining restaurants and discos (Table 4). If a super-emitting client entered a shop for 30 minutes, the resulting inhaled dose of the shop staff would be only slightly below the critical dose of 500 inhaled viruses. However, if all wore masks the levels would be well below the critical dose. In contrast, a client may inhale a critical dose if visiting late in the day a shop with the staff being a super-emitter not wearing a mask as the client would be exposed to a concentration above 2,000 viruses $\mathrm{m}^{-3}$. This exposure was markedly reduced had the staff worn a mask. 
Table 3. Office situations assessed with the indoor scenario simulator (Bold: inhaled dose > 500 copies).

\begin{tabular}{|c|c|c|c|c|c|c|}
\hline Scenario & $\begin{array}{l}\text { Room } \\
\text { size } \\
{\left[\mathrm{m}^{3}\right]}\end{array}$ & $\begin{array}{l}\text { Air } \\
\text { exchange } \\
\text { rate } \\
{\left[\mathrm{h}^{-1}\right]}\end{array}$ & $\begin{array}{l}\text { Final } \\
\text { room } \\
\text { concentration } \\
\text { [copies } \mathrm{m}^{-3} \text { ] }\end{array}$ & $\begin{array}{l}\text { Cumulative } \\
\text { dose, } \\
\text { person } \\
\text { in room } \\
\text { [copies] }\end{array}$ & $\begin{array}{l}\text { Final } \\
\text { near-field } \\
\text { concentration } \\
{\left[\text { copies } \mathrm{m}^{-3} \text { ] }\right.}\end{array}$ & $\begin{array}{l}\text { Cumulative } \\
\text { dose, person } \\
\text { in near-field } \\
\text { [copies] }\end{array}$ \\
\hline \multicolumn{7}{|c|}{4 hours in small room, different types of emitter and talk, moderate ventilation } \\
\hline normal emitter, $5 \%$ talk, no masks & 50 & 1 & 0.01 & 0.01 & 0.01 & 0.02 \\
\hline high emitter, $5 \%$ talk, no masks & 50 & 1 & 16 & 24 & 17 & 27 \\
\hline very high emitter, $5 \%$ talk, no masks & 50 & 1 & 631 & 966 & 694 & 1,080 \\
\hline super-emitter, $5 \%$ talk, no masks & 50 & 1 & 5,005 & 7,659 & 5,507 & 8,562 \\
\hline high emitter, $50 \%$ talk, no masks & 50 & 1 & 58 & 89 & 64 & 99 \\
\hline $\begin{array}{l}\text { high emitter, 50\% loud, no masks, poor } \\
\text { ventilation }\end{array}$ & 50 & 0.1 & 1,126 & 1,453 & 1,179 & 1,549 \\
\hline very high emitter, 50\% talk, no masks & 50 & 1 & 2,362 & 3,615 & 2,599 & 4,041 \\
\hline super-emitter, $50 \%$ talk, no masks & 50 & 1 & 18,731 & 28,666 & 20,609 & 32,046 \\
\hline super-emitter, $5 \%$ talk, all surgical masks & 50 & 1 & 1,251 & 479 & 1,376 & 536 \\
\hline super-emitter, $50 \%$ talk, all surgical masks & 50 & 1 & 4,683 & 1,792 & 5,152 & 2,003 \\
\hline \multicolumn{7}{|c|}{4 hours in same small room but with all windows open } \\
\hline very high emitter, $5 \%$ talk, no masks & 50 & 20 & 50 & 89 & 113 & 203 \\
\hline super-emitter, $5 \%$ talk, no masks & 50 & 20 & 396 & 706 & 898 & 1,609 \\
\hline super-emitter, $5 \%$ talk, all surgical masks & 50 & 20 & 99 & 44 & 224 & 101 \\
\hline \multicolumn{7}{|c|}{4 hours in open space office, moderate ventilation } \\
\hline very high emitter, $5 \%$ talk, no masks & 1000 & 1 & 32 & 48 & 95 & 162 \\
\hline super-emitter, $5 \%$ talk, no masks & 1000 & 1 & 250 & 383 & 752 & 1,286 \\
\hline super-emitter, 5\% talk, all surgical masks & 1000 & 1 & 63 & 24 & 188 & 80 \\
\hline \multicolumn{7}{|c|}{2 hours in meeting room, size for 10 people, good ventilation } \\
\hline super-emitter, $10 \%$ talk, no masks & 100 & 3 & 1,467 & 1,145 & 2,122 & 1,734 \\
\hline super-emitter, $10 \%$ talk, all surgical masks & 100 & 3 & 367 & 72 & 530 & 108 \\
\hline $\begin{array}{l}\text { super-emitter giving speech, } 50 \% \text { talk, } 5 \% \\
\text { loud, no masks }\end{array}$ & 100 & 3 & 7,988 & 6,234 & 11,552 & 9,441 \\
\hline $\begin{array}{l}\text { super-emitter giving same speech, all } \\
\text { surgical masks }\end{array}$ & 100 & 3 & 1,997 & 390 & 2,888 & 590 \\
\hline
\end{tabular}

The simulation of a fine dining restaurant (sitting down and staying for 1 hour) suggests that in places with moderate ventilation (AER: 1 per hour), inhaled doses can become critical. However, if the restaurant is very well ventilated (AER: 10 per hour), levels were below relevant exposures when assuming little talking at low voice. Wearing masks by asymptomatic infected staff will limit relevant exposure of clients. Also in the inverse situation, when the client is infected, the staff would profit from wearing a surgical mask because this resulted already in a relevant difference in estimated inhaled dose. Finally, the simulation of a disco with a dancing and shouting super-emitter suggests a very high risk of infection for everyone in the room. Everyone would need to wear good quality respirators (FFP2 or better) to not inhale critical doses, even when they did not increase their respiration by dancing.

\subsection{Transport Scenarios: Travel by Train, Bus, Car, and Air}

We also simulated different transport situations (Table 5). In all transport types, superemitters were predicted to cause high viral exposures especially when talking. In most cases, wearing surgical masks reduced the dose to levels that were below 500 inhaled viral copies. For similar transport distances, taking the train was better than taking a bus, while carpooling was worst. In a simulation of a long-distance bus ride of a group of sports fans or a choir with the emitter shouting or singing loudly during $20 \%$ of the travel time, not even surgical masks provided sufficient protection. For carpooling passengers or travelers in a taxi, the simulation showed that strong ventilation alone was not sufficient to reduce the exposure below presumably less critical 
Table 4. Situation in walk-in businesses such as small shops, boutiques, restaurants and discos (Bold: inhaled dose > 500 copies).

\begin{tabular}{|c|c|c|c|c|c|c|}
\hline Scenario & $\begin{array}{l}\text { Room } \\
\text { size } \\
{\left[\mathrm{m}^{3}\right]}\end{array}$ & $\begin{array}{l}\text { Air } \\
\text { Exchange } \\
\text { rate } \\
{\left[\mathrm{h}^{-1}\right]}\end{array}$ & $\begin{array}{l}\text { Final room } \\
\text { concentration } \\
\text { [copies } \mathrm{m}^{-3} \text { ] }\end{array}$ & $\begin{array}{l}\text { Cumulative } \\
\text { dose, person } \\
\text { in room } \\
\text { [copies] }\end{array}$ & $\begin{array}{l}\text { Final } \\
\text { near-field } \\
\text { concentration } \\
\text { [copies } \mathrm{m}^{-3} \text { ] }\end{array}$ & $\begin{array}{l}\text { Cumulative } \\
\text { dose, person } \\
\text { in near-field } \\
\text { [copies] }\end{array}$ \\
\hline \multicolumn{7}{|c|}{ Small shop / boutique, comparison of situation for client (short stay) and staff (long stay) } \\
\hline 30 minutes, super-emitter, $20 \%$ talk, no masks & 100 & 3 & 1,804 & 268 & 2,764 & 484 \\
\hline $\begin{array}{l}30 \text { minutes, super-emitter, } 20 \% \text { talk, all } \\
\text { surgical masks }\end{array}$ & 100 & 3 & 451 & 17 & 691 & 30 \\
\hline 4 hours, super-emitter, $20 \%$ talk, no masks & 100 & 3 & 2,154 & 3,619 & 3,115 & 5,347 \\
\hline $\begin{array}{l}4 \text { hours, super-emitter, } 20 \% \text { talk, all surgical } \\
\text { masks }\end{array}$ & 100 & 3 & 539 & 226 & 779 & 334 \\
\hline \multicolumn{7}{|c|}{ Fine dining restaurant, different ventilation settings, staff with/without mask } \\
\hline 2 hours, super-emitter, 20\% talk, no masks & 500 & 1 & 923 & 612 & 1,883 & 1,477 \\
\hline 2 hours, super-emitter, $20 \%$ talk, no masks & 500 & 10 & 147 & 127 & 1,108 & 991 \\
\hline $\begin{array}{l}2 \text { hours, super-emitter, } 20 \% \text { talk, emitter only } \\
\text { surgical mask }\end{array}$ & 500 & 1 & 231 & 153 & 471 & 369 \\
\hline $\begin{array}{l}2 \text { hours, super-emitter, } 20 \% \text { talk, receiver only } \\
\text { surgical mask }\end{array}$ & 500 & 1 & 923 & 153 & 1,883 & 369 \\
\hline \multicolumn{7}{|c|}{$\begin{array}{l}\text { Disco attended } 2 \text { hours by super-emitter, 20\% shouting loudly, 50\% heavy dancing, no mask. Situation for co-dancers and } \\
\text { resting persons with different mask settings }\end{array}$} \\
\hline co-dancers: moderate dancing, no masks & 300 & 3 & 9,730 & 15,186 & 22,752 & 38,625 \\
\hline resting persons: standing, no masks & 300 & 3 & 9,730 & 7,593 & 22,752 & 19,313 \\
\hline $\begin{array}{l}\text { resting persons: standing, receiver only surgical } \\
\text { mask }\end{array}$ & 300 & 3 & 9,730 & 1,898 & 22,752 & 4,828 \\
\hline resting persons: standing, receiver only FFP2 & 300 & 3 & 9,730 & 379 & 22,752 & 966 \\
\hline
\end{tabular}

levels, especially when the emitter was in the near-field of other passengers. The simulation of an intercontinental flight suggested that wearing masks kept the inhaled dose at low levels despite the long travel duration and intermittent talking by the emitter. Overall, these scenarios suggest that in transport situations, masks should be worn, and prolonged or loud speaking avoided, especially if the vehicle is small and the travel duration long.

\subsection{Reproduction of Super-spreading Events Described in the Literature}

We finally aimed to reproduce a number of documented super-spreading events (Table 6). Even when assuming a rather high AER of 3 exchanges per hour, the presence of a super-emitter not wearing a mask would always result in very high airborne virus concentrations. In the case of the fitness dance class in Chenoan, South-Korea (Jang et al., 2020) already a high emitter $\left(90^{\text {th }}\right.$ percentile) would have been sufficient to lead to an inhaled dose of the exposed dancers above 1,000 virus copies. For all these events, the airborne route would be a very plausible explanation if the virus carrier had been a super-emitter.

We also simulated the case of two hair stylists who serviced clients until they were tested positive (Hendrix et al., 2020). Both wore masks and no clients were infected. The clients were reported to have spent on average 15 minutes in the shop. We first assumed a worst case of two super-emitters in a small space with moderate ventilation. Not wearing a mask would lead to a cumulative inhaled dose of a few hundred viruses in the first client, while later clients would inhale several thousand viruses during the 15 minutes in the shop. The hair stylists wearing a surgical mask would keep the cumulative dose of the first client below 100 viruses while later clients would have gotten a dose of a few hundred viruses. However, if both stylists were median emitters, the airborne route would be very low and likely would contribute very little to the overall transmission risk even if neither wore a mask. Since we don't know the viral emitter strength of the stylists, it remains unclear whether the mask protected the customers from directly sprayed large droplets or from virus-loaded aerosols that had accumulated over time (Chu et al., 2020; Riediker, 2020). 
Table 5. Situations in transportation when travelling by train, bus, car and air (Bold: inhaled dose > 500 copies).

\begin{tabular}{|c|c|c|c|c|c|c|}
\hline Scenario & $\begin{array}{l}\text { Room } \\
\text { size } \\
{\left[\mathrm{m}^{3}\right]}\end{array}$ & $\begin{array}{l}\text { Air } \\
\text { Exchange } \\
\text { rate } \\
{\left[\mathrm{h}^{-1}\right]}\end{array}$ & $\begin{array}{l}\text { Final room } \\
\text { concentration } \\
\text { [copies } \mathrm{m}^{-3} \text { ] }\end{array}$ & $\begin{array}{l}\text { Cumulative } \\
\text { dose, } \\
\text { person } \\
\text { in room } \\
\text { [copies] }\end{array}$ & $\begin{array}{l}\text { Final } \\
\text { near-field } \\
\text { concentration } \\
\text { [copies } \mathrm{m}^{-3} \text { ] }\end{array}$ & $\begin{array}{l}\text { Cumulative } \\
\text { dose, } \\
\text { person } \\
\text { in near-field } \\
\text { [copies] }\end{array}$ \\
\hline \multicolumn{7}{|l|}{ Travelling by train, commute or long distance } \\
\hline 60 minutes, super-emitter, quiet, no masks & 57 & 7.1 & 644 & 255 & 993 & 412 \\
\hline 60 minutes, super-emitter, $20 \%$ talk, no masks & 57 & 7.1 & 1,774 & 702 & 2,734 & 1,134 \\
\hline $\begin{array}{l}60 \text { minutes, super-emitter, } 20 \% \text { talk, all } \\
\text { surgical masks }\end{array}$ & 57 & 7.1 & 444 & 44 & 684 & 71 \\
\hline 3 hours, super-emitter, quiet, no masks & 160 & 9.4 & 177 & 232 & 526 & 703 \\
\hline 3 hours, super-emitter, $20 \%$ talk, no masks & 160 & 9.4 & 487 & 638 & 1,448 & 1,934 \\
\hline $\begin{array}{l}3 \text { hours, super-emitter, } 20 \% \text { talk, all surgical } \\
\text { masks }\end{array}$ & 160 & 9.4 & 122 & 40 & 362 & 121 \\
\hline \multicolumn{7}{|l|}{ Trolleybus ride, 30 minutes with frequent stops } \\
\hline $\begin{array}{l}\text { doors open each stop, super-emitter, } 20 \% \text { talk, } \\
\text { no masks }\end{array}$ & 100 & 10 & 732 & 137 & 1692 & 353 \\
\hline $\begin{array}{l}\text { doors rarely open, super-emitter, } 20 \% \text { talk, no } \\
\text { masks }\end{array}$ & 100 & 2 & 2,175 & 305 & 3,136 & 521 \\
\hline $\begin{array}{l}\text { doors rarely open, super-emitter, } 20 \% \text { talk, all } \\
\text { surgical masks }\end{array}$ & 100 & 2 & 544 & 19 & 784 & 33 \\
\hline \multicolumn{7}{|l|}{ Regular long-distance bus ride, doors rarely open } \\
\hline 90 minutes, super emitter, $20 \%$ talk, no masks & 50 & 2 & 5,831 & 3,038 & 6,792 & 3,686 \\
\hline $\begin{array}{l}90 \text { minutes, super emitter } 20 \% \text { talk, all surgical } \\
\text { masks }\end{array}$ & 50 & 2 & 1,457 & 189 & 1,698 & 237 \\
\hline \multicolumn{7}{|c|}{ Sport fans or choir in long-distance bus, increased ventilation } \\
\hline 3 hours, super-emitter, $50 \%$ loud, no masks & 50 & 5 & 49,775 & 63,401 & 66,982 & 86,630 \\
\hline $\begin{array}{l}3 \text { hours, super-emitter, } 50 \% \text { loud, all surgical } \\
\text { masks }\end{array}$ & 50 & 5 & 12,444 & 3,963 & 16,745 & 5,414 \\
\hline \multicolumn{7}{|l|}{ Taxi or carpool, using mid-size (large family) car } \\
\hline $\begin{array}{l}30 \text { minutes, super-emitter, recirculation, } 10 \% \\
\text { talk, no masks }\end{array}$ & 3.3 & 10 & 15,120 & 2,834 & 15,775 & 2,981 \\
\hline $\begin{array}{l}30 \text { minutes, super-emitter, all fresh air, 10\% } \\
\text { talk, no masks }\end{array}$ & 3.3 & 40 & 3,976 & 864 & 4,630 & 1,011 \\
\hline $\begin{array}{l}30 \text { minutes, super-emitter, recirculation, 10\% } \\
\text { talk, all surgical masks }\end{array}$ & 3.3 & 10 & 3,780 & 177 & 3,943 & 186 \\
\hline \multicolumn{7}{|l|}{ Mini-Bus, people mover } \\
\hline 30 minutes, super-emitter, $20 \%$ talk, no masks & 20 & 5 & 6,529 & 1,064 & 7,409 & 1,250 \\
\hline $\begin{array}{l}30 \text { minutes, super-emitter, } 20 \% \text { talk, all } \\
\text { surgical masks }\end{array}$ & 20 & 5 & 1,632 & 66 & 1,072 & 80 \\
\hline \multicolumn{7}{|l|}{ Intercontinental flight } \\
\hline 10 hours, super-emitter, $10 \%$ talk, no masks & 700 & 10 & 72 & 320 & 726 & 3,265 \\
\hline $\begin{array}{l}10 \text { hours, super-emitter, } 10 \% \text { talk, all surgical } \\
\text { masks }\end{array}$ & 700 & 10 & 18 & 20 & 182 & 204 \\
\hline
\end{tabular}

\subsection{Discussion of the Method and Tool, Use and Limitations}

In our study, we developed an indoor scenario simulator that allows altering room volume, AER, type of virus spreader, physical activity, loudness of speech, wearing masks, type of mask and time spent in the indoor environment. Temperature, ultraviolet light intensity and humidity are not included because they were found to modify the half-life of SARS-CoV-2 only at conditions that are rarely present in indoor environments (Schuit et al., 2020). We applied the tool to a number of scenarios to show how different factors influence the predicted concentration and dose of virus copies in the room air and the near-field of an emitting person (within $0.6 \mathrm{~m}$ ). 


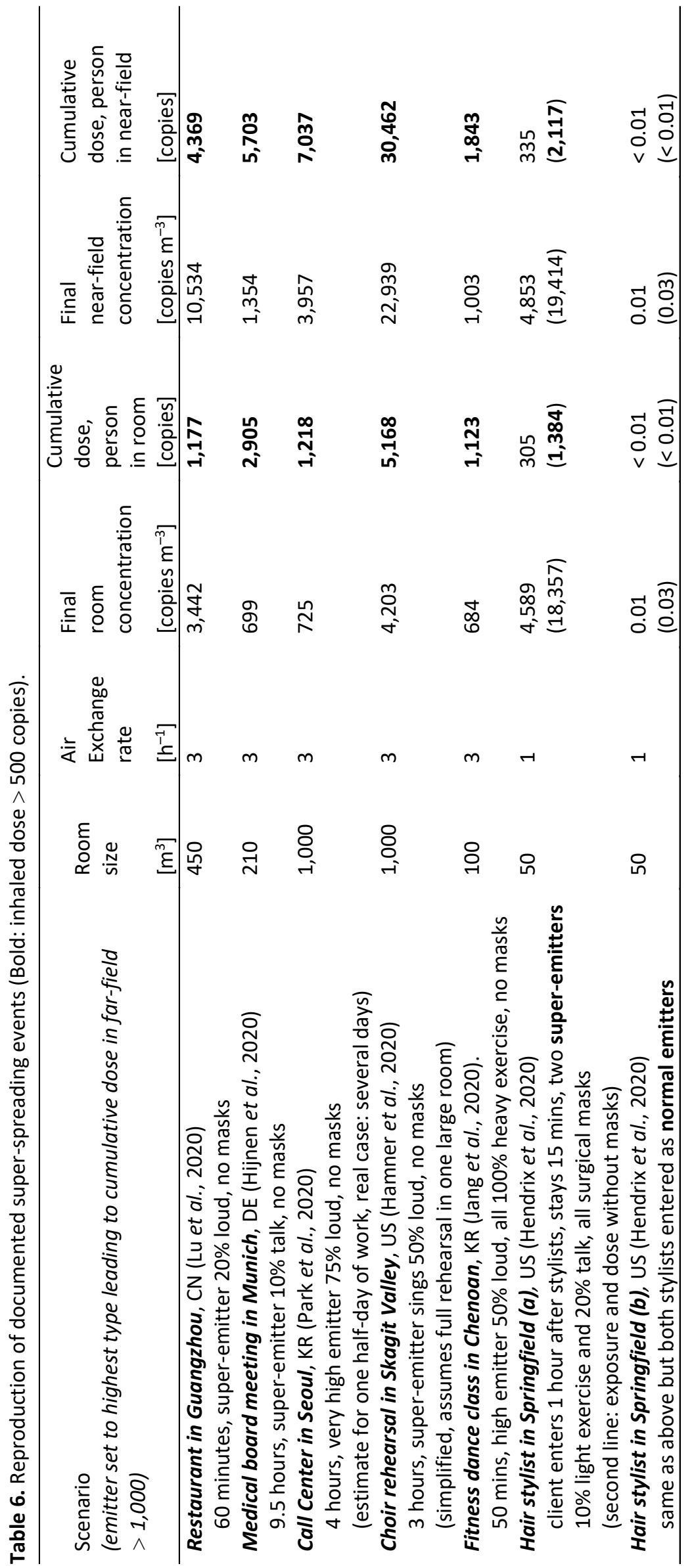


Decision makers, ventilation and occupational planners, occupational and public health experts, and other specialists can use this simulation tool to investigate their own indoor environment settings and scenarios. The critical dose, the number of viruses determined by PCR above which there seems to be an increased potential of infection, is subject to ongoing research and may be lower for vulnerable groups. It can therefore be easily adapted in the tool. In our simulator, the default of the critical dose was set to 500 inhaled viral copies because this seemed likely a level of low risk of infection for a healthy population as discussed in the introduction. However, for sensitive populations, lower levels seem advisable. The simulator allows to easily adjust the critical dose. It also provides the minimal contact time for reaching a given critical dose, which can be helpful to define a "safe time" in a room but also to study the importance of the timedose metric for COVID-19 infections (Pujol et al., 2009).

However, there are some limitations. First, the tool is based on a simple mass balance nearfield far-field model and its assumptions, such as well mixing of the airborne virus in the space. Second, sedimentation of aerosols was approximated by using the $\mathrm{PM}_{10}$ fraction of the emitted aerosols because calculating a real sedimentation term would require information on local airstreams and geometry. For short durations, this can underestimate the exposure because not all large aerosol will sediment immediately, while for longer durations, the influence of sedimentation may be underestimated. Thus, for critical scenarios, it would be advisable to use simulations with test aerosols or computational fluid dynamics approaches that assess the fate of all emitted particle sizes including the very large ones, and that takes into account inhomogeneous mixing of the air in a room. A third limitation is that aerosol data gained from healthy young people was used to calculate the emission strength. It is likely that the infection with SARS-CoV-2 causes changes in the aerosol size distribution, but it is not certain that this will be similar to what is known for upper respiratory tract diseases (Lee et al., 2019), given that asymptomatic individuals infected with the SARS-CoV-2 virus do not report typical upper respiratory tract disease symptoms. Fourth, the scenario-builder simplifies viral emissions by defining only one category of emitter-strength, even though high aerosol formation for breathing and talking were reported to not necessarily go together (Asadi et al., 2019). Fifth, the tool provides the number of viral copies determined by RNA testing (Jones et al., 2020), but for SARS-CoV-2 it is not yet known how RNA-copies measured in human liquids relate to infective, plaque-forming virus units (PFU). Finally, only transmission by aerosols is assessed. This has to be kept in mind in particular when looking at the near-field where spray-processes emitting large droplets are likely to lead to much higher virus exposures.

The here developed indoor scenario simulator allows assessing different factors influencing the airborne exposure to SARS-CoV-2 in a variety of indoor settings. The dose in many of the scenarios was below 500 virus copies, which seems to be a low risk for infection, as discussed earlier (Watanabe et al., 2010; Yezli and Otter, 2011; Karimzadeh et al., 2020; Sampath et al., 2005; Schröder, 2020). We also assessed the tool in comparison to documented super-spreading events. Our simulations suggest that these infective events could be explained by the airborne route and that an estimated dose of a few thousand virus copies may be sufficient to infect a large proportion of exposed people.

The risk of transmission and infection from exposure depends not only on the viral dose, but also on individual factors such as age, individual susceptibility, preexisting medical conditions and the correct use of protective measures. The airborne route is not the only way one can get infected with the virus, as seen by the effectiveness of hand washing, keeping distance and protecting the eyes when in close distance. We therefore opted against the calculation of a "quantum risk" (Buonanno et al., 2020) but prefer to simply report the estimated viral exposure levels and inhaled doses.

\section{CONCLUSIONS}

The here developed indoor scenario simulator allows estimating the viral exposure and inhaled dose in different indoor settings, based on a simulation of droplet generation and assumptions of indoor conditions. It was created to allow decision makers as well as workplace and facility experts to assess and improve their protection concepts, and to guide indoor exposure 
assessment campaigns. The tested scenarios document the positive effects of wearing masks and ventilation, and the contribution of viral load, speaking and physical activity. The parameter driving the risk is in most scenarios the emission rate of the infected person: the presence of a super-emitter (99.9\%) or very high emitter (99\%) was required to reach a critical number of inhaled copies. In very small rooms with poor ventilation (e.g., sitting in a car), already a high emitter (90\%) was sufficient, especially if the emitter was singing or talking loudly. Wearing simple surgical/hygiene masks was very effective in almost all cases. However, the retention rate of the different masks is based on the assumption of fit and proper wear by the infected emitters. Personal observation in public spaces suggests that this does not always hold, which has to be considered when doing risk assessments for populations that have difficulties following guidelines and rules.

The analysis of documented super spreading events suggests that the application of the simulator may be useful to predict worst-case scenarios. Preventive efforts should aim at preventing situations where people gather unprotected in small airspaces because in such situations, the presence of a single super-emitter can rapidly result in a super-spreading event. In such situations, mask should be worn, and people should be asked to remain quiet.

\section{ACKNOWLEDGMENTS}

This study was supported in part by Switzerland's State Secretariat for Economic Affairs (SECO) with a grant that explicitly encouraged publication of the findings. We would like to thank Samuel Iff, SECO, for his critical review of the manuscript.

\section{DISCLAIMER}

The contents of this article do not necessarily represent SECO policy, nor does mention of trade names or commercial products constitute endorsement or recommendation for use.

\section{SUPPLEMENTARY MATERIAL}

Supplementary data associated with this article can be found in the online version at https://doi.org/10.4209/aaqr.2020.08.0531

\section{REFERENCES}

Asadi, S., Wexler, A.S., Cappa, C.D., Barreda, S., Bouvier, N.M., Ristenpart, W.D. (2019). Aerosol emission and superemission during human speech increase with voice loudness. Sci. Rep. 9, 2348. https://doi.org/10.1038/s41598-019-38808-z

Bałazy, A., Toivola, M., Adhikari, A., Sivasubramani, S.K., Reponen, T., Grinshpun, S.A. (2006). Do N95 respirators provide 95\% protection level against airborne viruses, and how adequate are surgical masks? Am. J. Infect. Control 34, 2: 51-57. https://doi.org/10.1016/j.ajic.2005.08.018

Buonanno, G., Stabile, L., Morawska, L. (2020). Estimation of airborne viral emission: Quanta emission rate of SARS-CoV-2 for infection risk assessment. Environ. Int. 141, 105794. https://doi.org/10.1016/j.envint.2020.105794

Chandrashekar, A., Liu, J., Martinot, A.J., McMahan, K., Mercado, N.B., Peter, L., Tostanoski, L.H., Yu, J., Maliga, Z., Nekorchuk, M., Busman-Sahay, K., Terry, M., Wrijil, L.M., Ducat, S., Martinez, D.R., Atyeo, C., Fischinger, S., Burke, J.S., Slein, M.D., ... Barouch, D.H. (2020). SARS-CoV-2 infection protects against rechallenge in rhesus macaques. Science 369, 812-817. https://doi.org/10.1126/science.abc4776

Checchi, L., Montevecchi, M., Moreschi, A., Graziosi, F., Taddei, P., Violante, F.S. (2005). Efficacy of three face masks in preventing inhalation of airborne contaminants in dental practice. J. Am. Dent. Assoc. 136, 877-882. https://doi.org/10.14219/jada.archive.2005.0288

Chu, D.K., Akl, E.A., Duda, S., Solo, K., Yaacoub, S., Schünemann, H.J., Chu, D.K., Akl, E.A., Elharakeh, A., Bognanni, A., Lotfi, T., Loeb, M., Hajizadeh, A., Bak, A., Izcovich, A., Cuello-Garcia, 
C.A., Chen, C., Harris, D.J., Borowiack, E., Chamseddine, ... Schünemann, H.J. (2020). Physical distancing, face masks, and eye protection to prevent person-to-person transmission of SARSCoV-2 and COVID-19: A systematic review and meta-analysis. Lancet 395, 1973-1987. https://doi.org/10.1016/S0140-6736(20)31142-9

Coronaviridae Study Group of the International Committee on Taxonomy of Viruses (2020). The species Severe acute respiratory syndrome-related coronavirus: Classifying 2019-nCoV and naming it SARS-CoV-2. Nat. Microbiol. 5, 536-544. https://doi.org/10.1038/s41564-020-0695-z

Davies, A., Thompson, K.A., Giri, K., Kafatos, G., Walker, J., Bennett, A. (2013). Testing the efficacy of homemade masks: Would they protect in an influenza pandemic? Disaster Med. Public Health Prep. 7, 413-418. https://doi.org/10.1017/dmp.2013.43

Fruin, S.A., Hudda, N., Sioutas, C., Delfino, R.J. (2011). Predictive model for vehicle air exchange rates based on a large, representative sample. Environ. Sci. Technol. 45, 3569-3575. https://doi.org/10.1021/es103897u

Furukawa, N.W., Brooks, J.T., Sobel, J. (2020). Evidence supporting transmission of severe acute respiratory syndrome coronavirus 2 while presymptomatic or asymptomatic. Emerg. Infect. Dis. 26, 7. https://doi.org/10.3201/eid2607.201595

Hamner, L., Dubbel, P., Capron, I., Ross, A., Jordan, A., Lee, J., Lynn, J., Ball, A., Narwal, S., Russell, S., Patrick, D., Leibrand, H. (2020). High SARS-CoV-2 attack rate following exposure at a choir practice - Skagit County, Washington, March 2020. MMWR Morb. Mortal. Wkly. Rep. 69, 606-610. https://doi.org/10.15585/mmwr.mm6919e6

He, X., Reponen, T., McKay, R.T., Grinshpun, S.A. (2013). Effect of particle size on the performance of an N95 filtering facepiece respirator and a surgical mask at various breathing conditions. Aerosol Sci. Technol. 47, 1180-1187. https://doi.org/10.1080/02786826.2013.829209

Hendrix, M.J., Walde, C., Findley, K., Trotman, R. (2020). Absence of apparent transmission of SARS-CoV-2 from two stylists after exposure at a hair salon with a universal face covering policy - Springfield, Missouri, May 2020. MMWR Morb. Mortal. Wkly. Rep. 69, 930-932. https://doi.org/10.15585/mmwr.mm6928e2

Hijnen, D., Marzano, A.V., Eyerich, K., GeurtsvanKessel, C., Giménez-Arnau, A.M., Joly, P., Vestergaard, C., Sticherling, M., Schmidt, E. (2020). SARS-CoV-2 transmission from presymptomatic meeting attendee, Germany. Emerg. Infect. Dis. 26, 8. https://doi.org/10.3201/eid2608.201235

Hui, D.S., Chow, B.K., Chu, L., Ng, S.S., Lee, N., Gin, T., Chan, M.T.V. (2012). Exhaled air dispersion during coughing with and without wearing a surgical or N95 mask. PLoS ONE 7, e50845. https://doi.org/10.1371/journal.pone.0050845

Jang, S., Han, S.H., Rhee, J.Y. (2020). Cluster of coronavirus disease associated with fitness dance classes, South Korea. Emerg. Infect. Dis. 26, 8. https://doi.org/10.3201/eid2608.200633

Jones, R.M. (2020). Relative contributions of transmission routes for COVID-19 among healthcare personnel providing patient care. J. Occup. Environ. Hyg. 17, 408-415. https://doi.org/10.1080/ 15459624.2020.1784427

Jones, T.C., Mühlemann, B., Veith, T., Biele, G., Zuchowski, M., Hoffmann, J., Stein, A., Edelmann, A., Corman, V.M., Drosten, C. (2020). An analysis of SARS-CoV-2 viral load by patient age. medRxiv 2020.06.08.20125484 https://doi.org/10.1101/2020.06.08.20125484.

Karimzadeh, S., Bhopal, R., Nguyen Tien, H. (2020). Review of viral dynamics, exposure, infective dose, and outcome of COVID-19 caused by the SARS-CoV-2 Virus: Comparison with other respiratory viruses. Preprints 2020070613. https://doi.org/10.20944/preprints202007.0613.v3

Keil, C., Zhao, Y. (2017). Interzonal airflow rates for use in near-field far-field workplace concentration modeling. J. Occup. Environ. Hyg. 14, 793-800. https://doi.org/10.1080/15459 624.2017.1334903

Lee, J., Yoo, D., Ryu, S., Ham, S., Lee, K., Yeo, M., Min, K., Yoon, C. (2019). Quantity, size distribution, and characteristics of cough-generated aerosol produced by patients with an upper respiratory tract infection. Aerosol Air Qual. Res. 19, 840-853. https://doi.org/10.4209/ aaqr.2018.01.0031

Li, W., Zhang, B., Lu, J., Liu, S., Chang, Z., Cao, P., Liu, X., Zhang, P., Ling, Y., Tao, K., Chen, J. (2020). The characteristics of household transmission of COVID-19. Clin. Infect. Dis 71, 1943-1946. https://doi.org/10.1093/cid/ciaa450

Li, Y., Wong, T., Chung, J., Guo, Y.P., Hu, J.Y., Guan, Y.T., Yao, L., Song, Q.W., Newton, E. (2006). In vivo protective performance of N95 respirator and surgical facemask. Am. J. Ind. Med. 49, 
1056-1065. https://doi.org/10.1002/ajim.20395

Liu, Y., Eggo, R.M., Kucharski, A.J. (2020a). Secondary attack rate and superspreading events for SARS-CoV-2. Lancet 395, e47. https://doi.org/10.1016/S0140-6736(20)30462-1

Liu, Y., Ning, Z., Chen, Y., Guo, M., Liu, Y., Gali, N.K., Sun, L., Duan, Y., Cai, J., Westerdahl, D., Liu, X., Xu, K., Ho, K., Kan, H., Fu, Q., Lan, K. (2020b). Aerodynamic analysis of SARS-CoV-2 in two Wuhan hospitals. Nature 582, 557-560. https://doi.org/10.1038/s41586-020-2271-3

Lou, B., Li, T.D., Zheng, S.F., Su, Y.Y., Li, Z.Y., Liu, W., Yu, F., Ge, S.X., Zou, Q.D., Yuan, Q., Lin, S., Hong, C.M., Yao, X.Y., Zhang, X.J., Wu, D.H., Zhou, G.L., Hou, W.H., Li, T.T., Zhang, Y.L., ... Chen, Y. (2020). Serology characteristics of SARS-CoV-2 infection since exposure and post symptom onset. Eur. Respir. J. 56, 2000763. https://doi.org/10.1183/13993003.00763-2020

Lu, J., Gu, J., Li, K., Xu, C., Su, W., Lai, Z., Zhou, D., Yu, C., Xu, B., Yang, Z. (2020). COVID-19 outbreak associated with air conditioning in restaurant, Guangzhou, China, 2020. Emerg. Infect. Dis. 26, 7. https://doi.org/10.3201/eid2607.200764

Milton, D.K., Fabian, M.P., Cowling, B.J., Grantham, M.L., McDevitt, J.J. (2013). Influenza virus aerosols in human exhaled breath: Particle size, culturability, and effect of surgical masks. PLoS Pathog. 9, e1003205. https://doi.org/10.1371/journal.ppat.1003205

Nicas, M. (2016). The near field/far field model with constant application of chemical mass and exponentially decreasing emission of the mass applied. J. Occup. Environ. Hyg. 13, 519-528. https://doi.org/10.1080/15459624.2016.1148268

Park, S.Y., Kim, Y.M., Yi, S., Lee, S., Na, B.J., Kim, C.B., Kim, J.I., Kim, H.S., Kim, Y.B., Park, Y., Huh, I.S., Kim, H.K., Yoon, H.J., Jang, H., Kim, K., Chang, Y., Kim, I., Lee, H., Gwack, J., ... Jeong, E.K. (2020). Coronavirus disease outbreak in call center, South Korea. Emerg. Infect. Dis. 26, 8. https://doi.org/10.3201/eid2608.201274

Pfefferle, S., Guenther, T., Kobbe, R., Czech-Sioli, M., Noerz, D., Santer, R., Oh, J., Kluge, S., Oestereich, L., Peldschus, K., Indenbirken, D., Huang, J., Grundhoff, A., Aepfelbacher, M., Knobloch, J., luetgehetmann, M., Fischer, N. (2020). Low and high infection dose transmission of SARS-CoV-2 in the first COVID-19 clusters in Northern Germany. medRxiv 2020.06.11.20127332. https://doi.org/10.1101/2020.06.11.20127332

Pujol, J.M., Eisenberg, J.E., Haas, C.N., Koopman, J.S. (2009). The effect of ongoing exposure dynamics in dose response relationships. PLoS Comput. Biol. 5, e1000399. https://doi.org/10. 1371/journal.pcbi.1000399

Ramos, C.A., Reis, J.F., Almeida, T., Alves, F., Wolterbeek, H.T., Almeida, S.M. (2015). Estimating the inhaled dose of pollutants during indoor physical activity. Sci. Total Environ. 527-528, 111118. https://doi.org/10.1016/j.scitotenv.2015.04.120

Rengasamy, S., Eimer, B.C., Shaffer, R.E. (2010). Simple respiratory protection-Evaluation of the filtration performance of cloth masks and common fabric materials against $20-1000 \mathrm{~nm}$ size particles. Ann. Occup. Hyg. 54, 789-798. https://doi.org/10.1093/annhyg/meq044

Riediker, M. (2020). Nano-safety research lessons for dealing with aerosol transmissions of COVID-19. Nanotoxicology 14, 866-868. https://doi.org/10.1080/17435390.2020.1786185

Riediker, M., Tsai, D.H. (2020). Estimation of viral aerosol emissions from simulated individuals with asymptomatic to moderate coronavirus disease 2019. JAMA Netw. Open 3, e2013807. https://doi.org/10.1001/jamanetworkopen.2020.13807

Sampath, R., Hofstadler, S.A., Blyn, L.B., Eshoo, M.W., Hall, T.A., Massire, C., Levene, H.M., Hannis, J.C., Harrell, P.M., Neuman, B., Buchmeier, M.J., Jiang, Y., Ranken, R., Drader, J.J., Samant, V., Griffey, R.H., McNeil, J.A., Crooke, S.T., Ecker, D.J. (2005). Rapid identification of emerging pathogens: Coronavirus. Emerg. Infect. Dis. 11, 373-379. https://doi.org/10.3201/eid1103.040629

Schröder, I. (2020). COVID-19: A risk assessment perspective. ACS Chem. Health Saf. 27, 160-169. https://doi.org/10.1021/acs.chas.0c00035

Schuit, M., Ratnesar-Shumate, S., Yolitz, J., Williams, G., Weaver, W., Green, B., Miller, D., Krause, M., Beck, K., Wood, S., Holland, B., Bohannon, J., Freeburger, D., Hooper, I., Biryukov, J., Altamura, L.A., Wahl, V., Hevey, M., Dabisch, P. (2020). Airborne SARS-CoV-2 Is Rapidly Inactivated by Simulated Sunlight. J. Infect. Dis. 222, 564-571. https://doi.org/10.1093/infdis/jiaa334

Tian, Y., Rong, L., Nian, W., He, Y. (2020). Review article: Gastrointestinal features in COVID-19 and the possibility of faecal transmission. Aliment. Pharmacol. Ther. 51, 843-851. https://doi.org/10.1111/apt.15731

van Doremalen, N., Bushmaker, T., Morris, D.H., Holbrook, M.G., Gamble, A., Williamson, B.N., 
Tamin, A., Harcourt, J.L., Thornburg, N.J., Gerber, S.I., Lloyd-Smith, J.O., de Wit, E., Munster, V.J. (2020). Aerosol and Surface Stability of SARS-CoV-2 as Compared with SARS-CoV-1. N. Engl. J. Med. 382, 1564-1567. https://doi.org/10.1056/NEJMc2004973

Watanabe, T., Bartrand, T.A., Weir, M.H., Omura, T., Haas, C.N. (2010). Development of a doseresponse model for SARS coronavirus: Dose-response model for SARS-CoV. Risk Anal. 30, 1129-1138. https://doi.org/10.1111/j.1539-6924.2010.01427.x

Wen, Z., Yu, L., Yang, W., Hu, L., Li, N., Wang, J., Li, J., Lu, J., Dong, X., Yin, Z., Zhang, K. (2013). Assessment the protection performance of different level personal respiratory protection masks against viral aerosol. Aerobiologia 29, 365-372. https://doi.org/10.1007/s10453-012 9286-7

Wölfel, R., Corman, V.M., Guggemos, W., Seilmaier, M., Zange, S., Müller, M.A., Niemeyer, D., Jones, T.C., Vollmar, P., Rothe, C., Hoelscher, M., Bleicker, T., Brünink, S., Schneider, J., Ehmann, R., ZwirgImaier, K., Drosten, C., Wendtner, C. (2020). Virological assessment of hospitalized patients with COVID-2019. Nature 581, 465-469. https://doi.org/10.1038/s41586-020-2196-X

Yezli, S., Otter, J.A. (2011). Minimum infective dose of the major human respiratory and enteric viruses transmitted through food and the environment. Food Environ. Virol. 3, 1-30. https://doi.org/10.1007/s12560-011-9056-7

Zangmeister, C.D., Radney, J.G., Vicenzi, E.P., Weaver, J.L. (2020). Filtration efficiencies of nanoscale aerosol by cloth mask materials used to slow the spread of SARS-CoV-2. ACS Nano 14, 9188-9200. https://doi.org/10.1021/acsnano.0c05025

Zhang, R., Li, Y., Zhang, A.L., Wang, Y., Molina, M.J. (2020). Identifying airborne transmission as the dominant route for the spread of COVID-19. Proc. Natl. Acad. Sci. 117, 14857-14863. https://doi.org/10.1073/pnas.2009637117

Zheng, S., Fan, J., Yu, F., Feng, B., Lou, B., Zou, Q., Xie, G., Lin, S., Wang, R., Yang, X., Chen, W., Wang, Q., Zhang, D., Liu, Y., Gong, R., Ma, Z., Lu, S., Xiao, Y., Gu, Y., ... Liang, T. (2020). Viral load dynamics and disease severity in patients infected with SARS-CoV-2 in Zhejiang province, China, January-March 2020: Retrospective cohort study. BMJ 369, m1443 https://doi.org/10.1 136/bmj.m1443

Zou, L., Ruan, F., Huang, M., Liang, L., Huang, H., Hong, Z., Yu, J., Kang, M., Song, Y., Xia, J., Guo, Q., Song, T., He, J., Yen, H.L., Peiris, M., Wu, J. (2020). SARS-CoV-2 viral load in upper respiratory specimens of infected patients. N. Engl. J. Med. 382, 1177-1179. https://doi.org/10.1056/NEJ Mc2001737 